\title{
ORBIS as a Research Tool: Examination of the Capital Structure of the Hungarian and French Wine Industry
}

\author{
Martin Luptak \\ Bureau Van Dijk, Slovak Republic \\ Daniel Boda \\ Erste Bank, Slovak Republic \\ Gabor Szucs \\ Credit Reform Hungary, Hungary
}

\section{Abstract}

ORBIS is a global database and financial analysis tool offering company statements, ownership, rating and scores, news and intelligence. Global means the current coverage exceeds 165 million entities which most of them are private companies. However also listed companies, banks (over 35.000), insurance companies are included. And all that taking into consideration how different the legislations in countries are sometimes not only giving the free choice to companies when it comes to publish the reports but also forbids to do so (some Islamic jurisdictions). Goal of the paper is to demonstrate the usage of ORBIS in the examination of the capital structure of the Hungarian and French wine industry.

Keywords: ORBIS, capital structure, wine industry, discriminant analysis, profitability JEL classification: G32, C30

\section{Introduction}

Economics is the social science that seeks to describe the factors which determine the production, distribution and consumption of goods and services. It focuses on the behaviour and interactions of economic agents and how economies work. Consistent with this focus, primary textbooks often distinguish between microeconomics and macroeconomics.

Economic theories are frequently tested empirically, largely through the use of econometrics using economic data (Hashem and Pesaren, 1987). The controlled experiments common to the physical sciences are difficult and uncommon in economics (Keuzenkamp, 2000), and instead broad data is observationally studied; this type of testing is typically regarded as less rigorous than controlled experimentation, and the conclusions typically more tentative. However, the field of experimental economics is growing, and increasing use is being made of natural experiments.

Researcher often stands in front of the main question whether to collect the data by himself and set limits on quantity, sometimes also comparability of the examined population. Such approach can be accepted only in very limited number of cases. Obviously heaving by hand a comprehensive database of structured information allowing selecting populations by different and precise search options and building custom data sets is strongly appreciated.

Bureau Van Dijk was established in early 70's as Bureau Marcel Van Dijk. From 1991 it has become known as Bureau Van Dijk. The main focus from beginning was on 
quality and added value. The company is mostly known for its databases and tools like ORBIS, BankScope, AMADEUS, OSIRIS and more. Bureau Van Dijk has developed a unique process of collection and publishing of data from different providers and sources.

ORBIS is a global database and financial analysis tool offering company statements, ownership, rating and scores, news and intelligence. Global means the current coverage exceeds 165 million entities which most of them are private companies. However also listed companies, banks (over 35.000), insurance companies are included. And all that taking into consideration how different the legislations in countries are sometimes not only giving the free choice to companies when it comes to publish the reports but also forbids to do so (some Islamic jurisdictions).

Goal of the paper is to demonstrate the usage of ORBIS database in the examination of the capital structure of the Hungarian and French wine industry.

There are numbers of interesting books and articles written on this topic and some of them were used for research and writing this paper, such as: Altman (1968), Borszéki, (2008), Brealey, et al, (1999), Donaldson, (1961), Jensen, et al. (1976), Modigliani, et al. (1963), Myers, et al. (1984), Samuelson, et al. (1954), Stiglitz, (1972), Székelyi, et al. (2002), Szűcs, (2002), Viviani, (2008), Keuzenkamp, (2000), Hashem Pesaran, (1987) and Sajtos, Mitev,(2007).

\section{ORBIS Database}

ORBIS is a global database and financial analysis tool offering company statements, ownership, rating and scores, news and intelligence. Global means the current coverage exceeds 165 million entities which most of them are private companies. However also listed companies, banks (over 35.000), insurance companies are included (Table 1). And all that taking into consideration how different the legislations in countries are sometimes not only giving the free choice to companies when it comes to publish the reports but also forbids to do so (some Islamic jurisdictions).

Table 1

ORBIS coverage as published on 15/07/2015 update

\begin{tabular}{|c|c|c|c|}
\hline World regions/countries & Total & $\begin{array}{l}\text { of which } \\
\text { publicly listed companies }\end{array}$ & $\begin{array}{l}\text { of which } \\
\text { branches }\end{array}$ \\
\hline North America & $24,610,278$ & 14,547 & $3,378,404$ \\
\hline Western Europe & $53,208,405$ & 10,240 & $5,667,391$ \\
\hline Eastern Europe & $27,815,452$ & 7,846 & $1,276,076$ \\
\hline Middle East & $1,600,220$ & 1,928 & 128,471 \\
\hline Far East and Central Asia & $16,728,206$ & 23,064 & $2,434,415$ \\
\hline South and Central America & $25,719,883$ & 3,547 & $1,247,039$ \\
\hline Africa & $2,326,648$ & 1,332 & 67,321 \\
\hline Oceania & $11,987,954$ & 2,214 & $1,815,178$ \\
\hline Supranational & 60 & 0 & 0 \\
\hline No country specified & $1,119,297$ & 0 & 207 \\
\hline Total & $165,116,403$ & 64,718 & $16,014,502$ \\
\hline
\end{tabular}

Source: Bureau Van Dijk ORBIS

Another unique feature beside the coverage that lets it stand out from the crowd are standardized financial reports. Heaving in mind all the differences in accounting, language barriers and cultural differences. One global format allows any researcher 
to extend the scope from challenging few hundred or local companies to thousands and make it compare different markets in few clicks.

Ownership structure has always been one of the biggest assets of Bureau Van Dijk databases. And not only because of the coverage tracking direct and indirect relations even below 1\%. But also because of the live multilevel structures and the way how it is possible to search and filter within.

ORBIS is extremely powerful database when it comes in searching. It's anything like full text Google. Because of the unique structure of the data researcher can define sophisticated queries to select only companies from certain countries / regions, by industries, owners, subsidiaries (percentage, type of the entity, independence, country...), any financial item and ratio (value, growth, declination...), M\&A deals, etc. The queries are built using Boolean logic and be constructed as detailed as researches needs.

How the results are presented or analyzed corresponds with Bureau Van Dijk main philosophy of "leaving the steering in customers hands". User can define what should be displayed / exported, what currency; build custom lists and much more.

Main statistical functions like peer analyzes, segmentation aggregation, linear regression and distribution can be also used to analyze selected portfolio of comparables.

\section{Examination of the capital structure of the Hungarian and} French wine industry

The aim of this study is to analyze the capital structure of the Hungarian and the French wine industries and to examine the funding models, using ORBIS database. First, the database and the applied methods will be described followed by the descriptive statistical analysis of the industry. The analysis indicates the capital structure policy applied in the industry and, at the same time, evaluates its performance in terms of profitability and efficiency. The analysis examines the differences between the funding policies applied in the two countries, especially those variables that are the basis for the separation of the two branches. This was carried out by means of discriminant analysis, which indicates the financing characteristics. The main conclusion of the study is that the behaviour of the factors explaining the development of the capital structure is significantly different in the examined countries.

\section{Material and method}

The research is based on the ORBIS database, which contains details of more than 165 million companies. The screening was carried out on the basis of countries and areas of activity, selecting Hungary and France, with the 1102 grape wine production NACE code describing the wine production. Next, we divided the companies into separate tables according to countries, followed by the performance of the aggregation of the balance sheets and the financial indicators. In this way, we obtained the dataset concerning the individual countries and the values describing the whole branch. During the descriptive statistical analysis, we tried to take into consideration the greatest possible item number, as in this part, we aimed to describe the economy comprehensively. The number of the selected companies is 935 and 1498 for Hungary and France respectively, and this refers to those active companies that were part of the sector during the examined period. During the time series analysis, we examined those indicators that are mentioned by the specialized literature as well in connection with the capital structure and 
profitability. We paid attention to the fact that the indicators can be derived from companies' financial statements, so they will show the book value. The examined time period is 10 years, which will present all the processes of the wine growing sector of the examined countries that can be described by the available financial indicators. The multivariate discriminant analysis culminates in the form of a process that categorizes the observation units into pre-defined classes according to multiple variables (Altman, 1968). Basically, there are two types of discriminant analysis: bivariate and multivariate. In the first case, there are two categories, while in the latter case, there are more categories of the dependent variable.

In a mathematical sense, there is equality between the discriminant analysis and the multivariate variance analysis, but the discriminant analysis tries to answer completely different questions. In the case of a variance analysis, the question is whether the group membership is connected to a reliable average difference, while in the case of a discriminant analysis; the question is which of the variables based on the groups differ most from each other. The regression equation resulting from the regression analysis is similar to the discriminant function, but in the case of the regression, the dependent variable is estimated. The discriminant analysis estimates whether or not an observation belongs to the given group. A strikingly common characteristic of the discriminant analysis and the cluster analysis is that in both cases, groups are concerned. The difference between these is that in the case of the discriminant analysis, the groups are given in advance, and the purpose of the analysis is to determine a linear combination of the dependent variables that separate the groups to the largest degree. In the case of the cluster analysis, the groups are not developed in advance, and the purpose of the analysis is to find the best method for the categorization of the cases into the groups (Sajtos \& Mitev, 2006).

\section{Criteria of the analysis}

For the implementation of the analysis, we examined whether the following conditions are met: (i) the data do not correlate with each other; (ii) all observations of the dependent variable belong exclusively to one group; (iii) the group sizes are the same; (iv) there is a linear relationship between the independent variables; (vi) The normality was fulfilled; this was studied by means of the Kolmogorov-Smirnov test, which showed that this criterion was met.

By means of the Box's $M$ indicator, the congeniality of the covariance matrices has been stated. The alternative of the discriminant analysis is the logistic regression, which is more robust; however, the requirements of its use are less stringent. Accordingly, the run of the logistic regression analysis is recommended instead when there are some independent variables that are not metric, such as when the variance between the groups is not equal and the variables are not normally distributed. We have chosen the discriminant analysis because in the database, there is only one grouping variable, which refers to the countries, and the other conditions relating to the analysis are also met. These will be examined in further details.

\section{Results}

From 2007, the revenue of the Hungarian wine industry declined steadily until 2011. Then, in the following two years, the trend reversed, and the sector realized a significant increase. Although the current year's income in real terms is less than before the crisis, the value of 370 million EUR is $35 \%$ higher than the figures from 2011 , which were the lowest point. This is mainly due to the increase in the number of 
market leader companies. A number of companies have been founded in the last five years and have since become significant in the sector. In 2013, the revenue of the French wine industry was more than twenty times that of the Hungarian industry; however, apart from in 2014, the growth here is constant. While the value of the 8.27 billion EUR is 100 million EUR less than a year earlier, that is, 2012, it is higher both in nominal and in real terms than in 2008. The Hungarian wine industry cannot be considered to be concentrated. Half of the total revenue is concentrated in 12 companies; 106 firms provide $90 \%$ of the revenue. The proportions are similar in the French sector as well., with 250 companies making up $90 \%$.

Figure 1

Profit margin in selected countries, 2004-2013 (left) and the proportion of the current and non-current liabilities in the Hungarian wine producing sector (right)

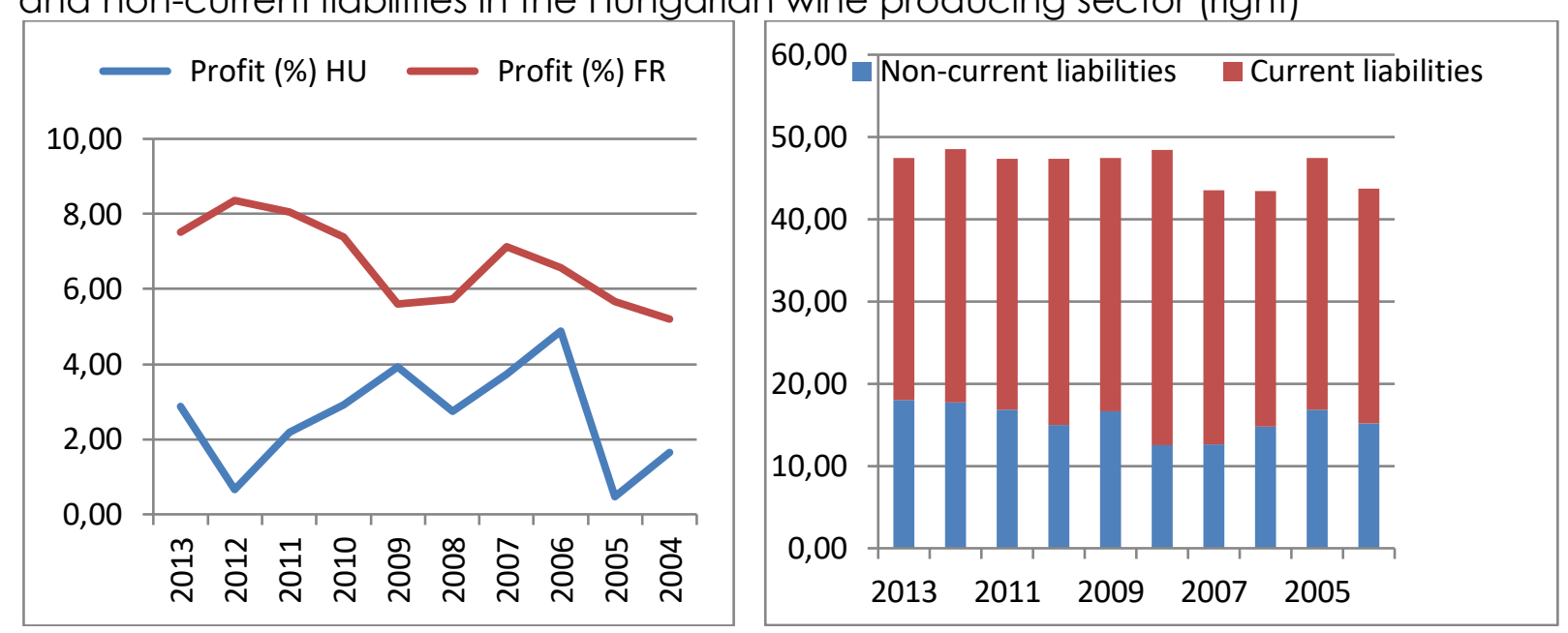

Source: Authors' calculation based on the ORBIS database

In terms of profitability, the explanation is quite complex (Figure 1). The profit margin was the highest in 2006, but it had not reached the $5 \%$ level even then. The lowest points were in 2005 and 2012 when the indicator was less than 1\%. The sector improved in the current year; the value of the $2.88 \%$ is about average for the examined period. The French wine manufacturers are characterized by a higher profitability; even the indicator of the weakest year exceeds the best Hungarian values, and the shape of the curve is different. The proportion of the liabilities was under $50 \%$ within the liabilities and equities in the Hungarian wine growing industry each year (Figure 1). A similar trend can be observed in the case of the long-term loans (Figure 2). In addition to the growth, it is remarkable that in four years, the number of companies in whose balance sheets the loan with the given term can be found has increased by 34. In this context, the growth of the rate of the tangible fixed assets can be observed as well. By comparing the two graphs, it is clear that the two curves move virtually completely together. The local peak and the lowest points are the same everywhere. The proportion of the suppliers shows a decrease; the indicator moved between 16 and $17 \%$ in recent years, while between 2007 and 2009 , we can see successively a value of over $20 \%$. 
Figure 2

The proportion of the non-current liabilities and the fixed assets in the Hungarian wine-growing industry (left) and the proportion of the current and non-current liabilities in the French wine-producing sector (right)

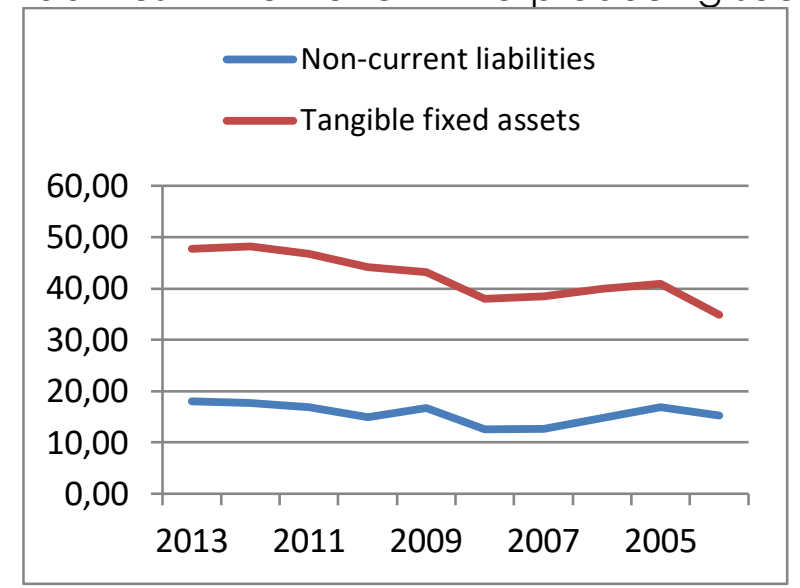

Non-current liabilities $\square$ Current liabilities

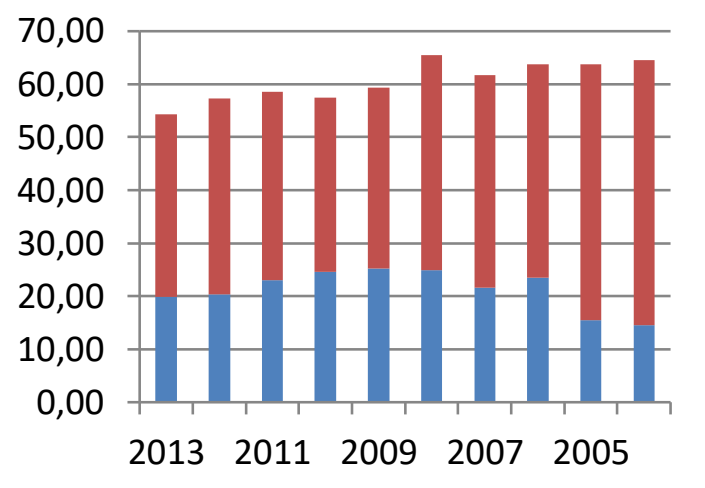

Source: Authors' calculation based on the ORBIS database

The proportion of the liabilities is more significant in the French enology, which in contrast to the Hungarian, exceeds $50 \%$ each year. Before 2006 , it was constantly over 60\% (Figure 4). However, in the 10 years since 2004, a general decreasing trend can be observed as well, except for two years when the proportion of the liabilities was each year lower than in the previous year. Otherwise, the peak was in 2008, when the proportion of the liabilities was $65.4 \%$. The $54.2 \%$ of the current year is the lowest value of the examined period, considering its proportion the Hungarian level. The ratio of the fixed assets shows a balanced picture in the last 10 years (Figure 3). Therefore, we could not find a similar correlation with the non-current liabilities, as is the case of the Hungarian sector. Due to the low proportion of fixed assets, we conclude that the proportions of the assets that can be involved as provision do not have such a significant role in lending in the Hungarian market. Furthermore, the current assets and, within this, the proportion of the stocks, plays a significant role in the composition of the assets. The indicator over the last five years was over $50 \%$ in the French sector, while in the Hungarian market, it did not reach $30 \%$.

Figure 3

The proportion of non-current liabilities and fixed assets in the French wine-growing sector

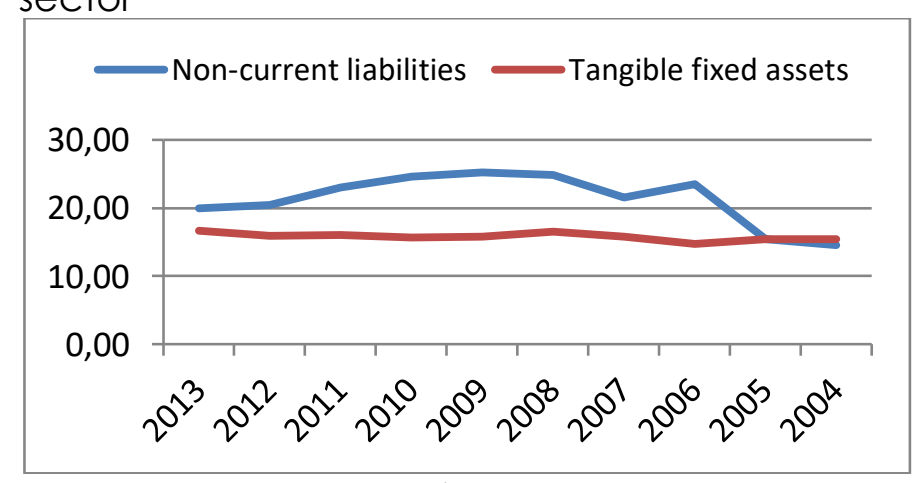

Source: Authors' calculation based on the ORBIS database

Next, we examined the 50 Hungarian and French companies with the highest revenue by means of discriminant analysis. The aim of the analysis is to show all the 
variables that affect the discriminant function, that is, to separate the two groups from each other. Using a boxplot, the salient values were filtered out, so the sample finally comprised in total $40-40$ enterprises in which $70 \%$ and the $60 \%$ of the 2013 revenue of the French and Hungarian sector respectively are concentrated.

The analysis was carried out by applying three different indicator-structures for the year 2013 so that the conditions would be met. The income situation and the solvency are presented by means of the Table 2.

Table 2

The income situation and the solvency

\begin{tabular}{|l|l|l|l|l|l|}
\hline & Wilks' Lambda & F & df1 & df2 & Sig. \\
\hline Return on Equity &, 993 &, 532 & 1 & 78 &, 468 \\
\hline Return on Assets &, 994 &, 456 & 1 & 78 &, 501 \\
\hline Profit\% &, 989 &, 875 & 1 & 78 &, 352 \\
\hline EBIT\% &, 994 &, 497 & 1 & 78 &, 483 \\
\hline Turnover/Total Assets &, 966 & 2,726 & 1 & 78 &, 103 \\
\hline Liquidity ratio & 1,000 &, 011 & 1 & 78 &, 918 \\
\hline
\end{tabular}

Source: Authors' calculation based on the ORBIS database

In Table 3, it is worth noting the Wilk's Lambda indicator and the significant level related to the single indicators. The Lambda value related to the $\mathrm{F}$ test shows the extent to which the independent variable contributes to both the discriminant line and the discriminant function. The indicator can take the values between 0 and 1 ; the smaller it is, the more significant its effect is on the function. By means of the significant levels and the related Lambda value, it can be concluded that the countries are not separated by these indicators. However, it would be worthwhile examining which country performs better regarding the year 2013 (Table 2).

According to the averages, the profitability of the Hungarian sector proved to be better when based on the assets and on the proportional indicator of the shareholders' fund, but the high standard deviation indicates significant differences between the performances of the single companies. Compared to the aggregate indicators of the examined 40 companies we obtain a much lower value 15,3 respectively 2,7). However, in the French sector, the opposite is the case: the aggregate values show a significantly higher value $(12,5$ respectively 4,9$)$, which can be explained by the performance of the companies with a dominant market share.

These differences appeared in the case of the other indicators as well, so it is ascertainable that the profitability indicators of the sampled companies that have the greatest revenue by countries show significant differences compared to both the average gained from them and to the aggregate values. This difference is more significant in the case of the Hungarian sector.

Table 3

The group statistics

\begin{tabular}{|l|l|l|l|l|}
\hline \multirow{2}{*}{ Indicators } & \multicolumn{3}{l|}{ Hungarian } & French \\
\cline { 2 - 5 } & Avg. & St.Dev. & Avg. & St.Dev. \\
\hline Return on Equity & 9,4598 & 16,06088 & 7,4150 & 7,51032 \\
\hline Return on Assets & 3,7095 & 5,50615 & 3,0415 & 2,96722 \\
\hline Profit\% & 4,0880 & 9,75579 & 5,8043 & 6,28460 \\
\hline EBIT\% & 5,5463 & 9,73169 & 6,8788 & 6,94439 \\
\hline Liquidity ratio &, 6745 &, 42839 &, 6655 &, 34920 \\
\hline Turnover/Total Assets & 78,7645 & 49,47812 & 63,5518 & 30,79301 \\
\hline
\end{tabular}

Source: Authors' calculation based on the ORBIS database 
In the case of the second run, we examined the impact on the discriminant line of the tax effect and of the proportion of the current and non-current liabilities, which will be shown again by the ANOVA table (Table 4).

\section{Table 4}

Impact on the discriminant line of the tax effect and of the proportion of the current and non-current liabilities

\begin{tabular}{|l|l|l|l|l|l|}
\hline & Wilks' Lambda & F & df1 & df2 & Sig. \\
\hline Tax effect &, 995 &, 407 & 1 & 78 &, 525 \\
\hline Proportion of the non-current liabilities &, 963 & 3,024 & 1 & 78 &, 086 \\
\hline Proportion of the current liabilities &, 967 & 2,635 & 1 & 78 &, 109 \\
\hline
\end{tabular}

Source: Authors' calculation based on the ORBIS database

As can be seen from the second ANOVA table, the proportion of the non-current liabilities of the three indicators could be accepted at most in the case of a $10 \%$ significance. The remaining two significant levels - related to the F-test - are too high. However, it is useful to examine this at an average level to provide a comparison of the two countries (see Table 5).

Table 5

Group statistics II

\begin{tabular}{|l|l|l|l|l|}
\hline \multirow{2}{*}{ Indicators } & Hungarian & \multicolumn{2}{l|}{ French } \\
\cline { 2 - 5 } & Avg. & St.Dev. & Avg. & St.Dev. \\
\hline Proportion of non-current liabilities & 11,1970 & 11,96667 & 17,3735 & 19,01037 \\
\hline Proportion of current liabilities & 36,0538 & 16,38838 & 42,1595 & 17,24270 \\
\hline Tax effect & 7,3815 & 14,26998 & 12,4315 & 47,96264 \\
\hline
\end{tabular}

Source: Authors' calculation based on the ORBIS database

Based on this, the external financing in the case of the French can be considered to be much more a majority financial form both among those within the year and among those over the year. However, the dispersion declares that the rate of utilization of the resources is much more diversified in the case of the French. Examining the tax effect at an average level, it is ascertainable that the French perform a tax liability of a greater volume. However, it should be noted that the rate of the French income tax is $33 \%$, which is more than double the Hungarian rate of $16 \%$ (http://hu.tradingeconomics.com/france/corporate-tax-rate).

By the third execution, the variables that were analyzed were those that actually affected the discriminant function - Table 6, that shows us that all four variables affect the discriminant function significantly, and the Lambda value relating to them is lower than was shown previously in the other cases.

Table 6

Variables affecting the discriminant function

\begin{tabular}{|l|l|l|l|l|l|}
\hline & Wilks' Lambda & F & df1 & df2 & Sig. \\
\hline Proportion of the fixed assets &, 707 & 32,277 & 1 & 78 &, 000 \\
\hline Proportion of the equity &, 889 & 9,750 & 1 & 78 &, 003 \\
\hline Export earnings against the revenue &, 952 & 3,962 & 1 & 78 &, 050 \\
\hline Net working capital &, 933 & 5,565 & 1 & 78 &, 021 \\
\hline
\end{tabular}

Source: Authors' calculation based on the ORBIS database

Table 7 shows that the rate of the fixed assets represents a more significant proportion in the Hungarian sector in the examined year, in the sample that comprises 40-40 companies. The proportion of the fixed assets can be considered as indicating a considerable assets portfolio in many instances, especially in the cases 
of those companies where external financing is preferred with the existence of different asset coverage. Returning to the previous companies, it can be concluded that the proportion of the loans is higher for the French, but also the rate of the fixed assets is lower there. This can be explained by the high proportion of unsecured liabilities.

Table 7

Correlation of the centres and the variables

\begin{tabular}{|l|l|l|l|}
\hline \multirow{2}{*}{ Country } & Function & & Function \\
\cline { 2 - 4 } & 1 & & 1 \\
\hline Hungarian &, 734 & Proportion of the fixed assets &, 866 \\
\hline French &,- 734 & Proportion of the equity &, 476 \\
\hline & & Net working capital &,- 360 \\
\hline & & Export earnings against the revenue &,- 303 \\
\hline
\end{tabular}

Source: Authors' calculation based on the ORBIS database

The rate of equity is higher in the financing by the Hungarian enterprises, which is supported by the fact that the proportion of the various current and non-current liabilities is lower. Based on this, it is ascertainable that the French actually prefer the external resources, primarily the short-term ones, due to the lower interest rates. In the case of financing, it can be assumed that the Hungarian companies follow a less aggressive financing policy, but let us examine the value of the net working capital. The index can be calculated as the difference of the temporary assets and the temporary liabilities.

\section{Conclusions}

The national culture of the wine industry in France is totally supported by the given financial indicators. It is clear that the French wine industry's total revenue is twenty times greater than that of Hungary at an aggregate level, and its profitability is significantly higher. Although important issues need to be clarified, the French market is expected to receive more in exports, and there are differences in the number of companies. Discriminant analysis offers a similar result. This method also reveals that regarding profitability, the Hungarian companies have a higher level of effectiveness compared to the French, although a higher standard deviation can be seen on descriptive statistics, which means simultaneously greater differences and shifts compared to the average in the smooth operation of companies. Nevertheless, it raises the possibility of an increase in effectiveness globally.

The coverage of tangible assets, the equity rate, and the observed difference via discriminant analysis regarding the effectiveness indicate a prosperous line for future development in part due to the creditworthiness of the companies, although the profitability and the possible performance of the future cannot be guaranteed. Currently, the sector is being subsidized by government programs. However, it is expected that not only do the money and capital markets need to be developed, but simultaneously, the internal processes of the companies need to be evolved.

\section{References}

1. Altman, E. I. (1968), "Financial ratios, discriminant analysis and the prediction of corporate bankruptcy". The Journal of Finance Vol. 23 No. 4, pp. 589-609.

2. Borszéki, É. (2008), "Vállalati pénzügyek" ("Corporate Finance"), Szent István Egyetemi Kiadó, Gödöllő.

3. Brealey, R. A., Myers, S. C. (1999), "Modern vállalati pénzügyek" ("Modern Corporate Finance"), Panem Kft., Budapest. 
4. Donaldson, G. (1961), "Corporate Debt Capacity: A Study of Corporate Debt policy and the Determinants of Corporate Debt Capacity", Harvard Business School, Division of Research, Harvard University.

5. Hashem Pesaran, M. (1987), "Econometrics," The New Palgrave: A Dictionary of Economics, Vol. 2, pp. 8-22. Reprinted in J. Eatwell et al., eds. (1990). "Econometrics", The New Palgrave, pp. 1-34. Abstract (2008 revision by J. Geweke, J. Horowitz, and H. P. Pesaran).

6. Jensen, M.C., Meckling, W.H. (1976), "Theory of the Firm: Managerial Behaviour, Agency Costs and Ownership Structure", Journal of Financial Economics, Vol. 3, pp. 305-360.

7. Keuzenkamp, H. A. (2000), "Probability, econometrics and truth: the methodology of econometrics", Published by Cambridge University Press, pp. 13.

8. Modigliani, F. Miller, M. H. (1963), "Corporate income taxes and the cost of capital: a correction", The American Economic Review, Vol. 53 No. 2, pp. 433-443.

9. Myers, S.C., Majluf, N.S. (1984), "Corporate financing and investment decisions when firms have information that investors do not have", Journal of Financial Economics, Vol. 13, pp. 187-221.

10. Sajtos L., Mitev A. (2007), "SPSS kutatási és adatelemzési kézikönyv" ("SPSS Research and Data Analysis Manual"), Alenia Kiadó, Budapest.

11. Samuelson, P.A., Koopmans, T. C., Stone J.R.N. (1954), "Report of the Evaluative Committee for Econometrica," Econometrica Vol. 22 No. 2, pp. 141-146

12. Stiglitz, J. (1972), "Some aspects of the pure theory of corporate finance: bankruptcies and take-overs", Bell Journal of Economics and Management Science, Vol. 3, pp. 458482.

13. Székelyi M., Barna I. (2002) "Túlélőkészlet az SPSS-hez" ("SPSS Survival Kit Offer"), Typotex Kiadó, Budapest.

14. Szúcs, I. (2002) "Alkalmazott statisztika" ("Applied Statistics"), Agroinform Kiadó, Budapest.

15. Viviani, J.-L. (2008), "Capital Structure Determinants: An Empirical Study of French Companies in the Wine Industry". International Journal of Wine Business Research, Vol. 20 No. 2, pp. $171-194$.

\section{About the authors}

Martin Luptak works for Bureau Van Dijk since 2007. Currently he is working as Central and Eastern Europe Key Account Manager. He is responsible for developing Compliance, Transfer Pricing, Credit risk markets in the region and managing the South sales team. Martin started his career in 2003 as Fundraising manager at Greenpeace right After finishing the Political science and International Relations faculty in Banska Bystrica. Author can be contacted at martin.luptak@bvdinfo.com

Daniel Boda graduated at the faculty of Finance at Szent Istvan University-Gödöllö. Nowdays he works at Erste Bank in the Risk-Management Department, dealing with corporate risk and in the same time he is developing a probability of default model for Eastern European companies. His MSc thesis won a special award on the so called Scientific Students Associations (TDK) Competition. He starts his PhD studies from this September at Gödöllő.

Gabor Szucs is a managing director of Creditreform Hungary, previously he worked in the market research industry. He graduated at the Corvinus University Budapest at the faculty of sociology and economics than on the Budapest Business School at the faculty of Risk Management. He started his Ph.D. studies last year on the field of capital structure and corporate finance. Being involved in several international projets within the Creditreform group, from 2015 January he also holds the position Sales and Marketing Director at AM Holding, owner of 6 Creditreform offices worldwide. Author can be contacted at szucs.gabor@creditreform.hu 